BMJ Paediatrics Open

\title{
Persistent clinical features in paediatric patients after SARS-CoV-2 virological recovery: a retrospective population- based cohort study from a single centre in Latvia
}

\author{
Liene Smane (D) , ${ }^{1,2}$ Inese Stars, ${ }^{3}$ Zanda Pucuka, ${ }^{1,2}$ leva Roge, ${ }^{2}$ Jana Pavare ${ }^{1,2}$
}

\begin{abstract}
To cite: Smane L, Stars I, Pucuka Z, et al. Persistent clinical features in paediatric patients after SARS-CoV-2 virological recovery: a retrospective populationbased cohort study from a single centre in Latvia. BMJ Paediatrics Open 2020;4:e000905. doi:10.1136/ bmjpo-2020-000905
\end{abstract}

Received 8 0ctober 2020 Accepted 8 December 2020

D) Check for updates

(C) Author(s) (or their employer(s)) 2021. Re-use permitted under CC BY-NC. No commercial re-use. See rights and permissions. Published by BMJ.

${ }^{1}$ Department of Paediatrics, Riga Stradins University, Riga, Latvia ${ }^{2}$ Department of Paediatrics, Children's Clinical University Hospital, Riga, Latvia ${ }^{3}$ Department of Public Health and Epidemiology, Riga Stradins University, Riga, Latvia

Correspondence to Dr Liene Smane; Liene.Smane@ gmail.com

\section{ABSTRACT}

The COVID-19 related state of emergency in Latvia was declared on 12 March 2020. Consequently, Children's Clinical University Hospital in Riga, Latvia, established a postacute outpatient service for individuals after recovery from COVID-19. Although information regarding the epidemiology and clinical features of COVID-19 in children has accumulated, relevant reports about persistent symptoms after recovery are lacking. We aimed to determine data on COVID-19 persistent symptoms after recovery in children in Latvia. Persistent symptoms have been reported in 9 out of 30 children.

Introduction Studies have shown that the COVID-19 was predominantly more prevalent among adults. Furthermore, children were less affected clinically by SARS-CoV-2 and had much lower mortality than adults. ${ }^{1-3}$ To date, information on COVID-19 persistent symptoms after recovery in children and adolescents remain scarce, despite the number of confirmed COVID-19 cases worldwide. A recent report from Italy on 143 adults with COVID-19, described persistent symptoms after recovery. Common symptoms included fatigue, dyspnoea, joint pain, chest pain, cough and anosmia. ${ }^{4}$ COVID-19 can result in prolonged illness, even among adults without chronic medical conditions and milder clinical course. ${ }^{5}$ The most common symptoms of acute COVID-19 in children are fever, cough, rhinorrhoea and nasal congestion. ${ }^{6}$ This study aimed to rapidly capture data on COVID-19 persistent symptoms after recovery in children in Latvia.

\section{METHODS}

Children's Clinical University Hospital in Riga, Latvia, established a postacute outpatient service for individuals after recovery from COVID-19. All hospitalised and nonhospitalised patients with two negative test results for SARS-CoV-2 24 hours apart were followed up. Real-time PCR for COVID-19 was used. We systematically screened for viral coinfections. At our tertiary care centre 30 cases of SARS-CoV-2-positive children (0-17 years of age) after recovery from COVID-19 and their caregivers (parents or legal family representatives) were enrolled in a retrospective cohort study through 31 July 2020. Caregivers had to provide written consent. Patients were tendered a comprehensive medical assessment with physical examination and detailed epidemiological history. Data on demographic characteristics, vaccination status, baseline chronic medical conditions, clinical features during the acute phase of SARS-CoV-2, and clinical symptoms persistent at the time of the visit were collected in a structured questionnaire (filled-in by the medical staff). The studied population was described via descriptive statistics.

\section{RESULTS}

From 1 July to 31 July 2020, 30 patients were followed up for the postacute care assessment. Most affected children had a mild or moderate illness. Of the 30 patients, 5 have been hospitalised and did not require admission to the intensive care unit. The mean age of patients with COVID-19 during this time was 9.2 (SD, 5.2 ) years (range, 3 months -17 years). Of them $17(56.7 \%)$ were boys. Of seven children with chronic medical conditions data available, three had bronchial asthma, one epilepsy, one attention deficit disorder, one patent ductus arteriosus and one after heart transplantation in January 2018 due to left heart hypoplasia syndrome. Among all 30 


\begin{tabular}{|c|c|}
\hline Characteristics & Value \\
\hline Age, mean (SD), years & $9.2(5.2)$ \\
\hline \multicolumn{2}{|l|}{ Age group, n (\%) } \\
\hline 1 month to $<1$ year & $1(3)$ \\
\hline $1-4$ years & $5(17)$ \\
\hline $5-9$ years & $9(30)$ \\
\hline $10-14$ years & $10(33)$ \\
\hline $15-17$ years & $4(13)$ \\
\hline Girls, n (\%) & $13(43)$ \\
\hline Boys, n (\%) & $17(57)$ \\
\hline \multicolumn{2}{|l|}{ Vaccination, n (\%) } \\
\hline Seasonal influenza & $4(13)$ \\
\hline$B C G$ & $30(100)$ \\
\hline MMR & $29(97)$ \\
\hline $\begin{array}{l}\text { Total baseline chronic medical } \\
\text { conditions, } \mathrm{n}(\%)\end{array}$ & $7(23)$ \\
\hline Bronchial asthma & $3(10)$ \\
\hline Congenital heart disease & $2(7)$ \\
\hline Attention deficit disorder & $1(3)$ \\
\hline Epilepsy & 1 (3) \\
\hline $\begin{array}{l}\text { Immunosuppressant use before } \\
\text { presentation, } \mathrm{n}(\%)\end{array}$ & $1(3)$ \\
\hline
\end{tabular}

Acute COVID-19 symptoms, $\mathrm{n}(\%)$

\begin{tabular}{|lc}
\hline Fever, $\mathrm{n}(\%)$ & $5(17)$ \\
\hline$\geq 37.5^{\circ} \mathrm{C}-38^{\circ} \mathrm{C}$ & $4(13)$ \\
\hline $38.1^{\circ} \mathrm{C}-39.0^{\circ} \mathrm{C}$ & $5(17)$ \\
\hline$>39.0^{\circ} \mathrm{C}$ & $8(27)$ \\
\hline Rhinorrhoea & $7(23)$ \\
\hline Cough & $7(23)$ \\
\hline Fatigue & $7(23)$ \\
\hline Headache & $7(23)$ \\
\hline Stuffy nose & $6(20)$ \\
\hline Sneezing & $6(20)$ \\
\hline Sore throat & $4(13)$ \\
\hline Diarrhoea & $3(10)$ \\
\hline Anosmia & $2(7)$ \\
\hline Ageusia & $2(7)$ \\
\hline Poor appetite & $1(3)$ \\
\hline Myalgia & $1(3)$ \\
\hline Shortness of breath & $1(3)$ \\
\hline Conjunctivitis & $1(3)$ \\
\hline Ear pain & $1(3)$ \\
\hline Vomiting & \\
\hline Severity of illness, $\mathrm{n}(\%)$ & $5(17)$ \\
\hline Asymptomatic & $24(80)$ \\
\hline Mild & $1(3)$ \\
\hline Moderate & \\
\hline & \\
\hline
\end{tabular}

Table 2 Post-COVID-19 follow-up clinical features

\begin{tabular}{ll}
\hline Clinical features & Value \\
\hline Prolonged low-grade fever & $2(6.7)$ \\
Joint pain & $1(3.3)$ \\
Headache & $1(3.3)$ \\
Anosmia & $1(3.3)$ \\
Ageusia & $1(3.3)$ \\
Microhaematuria & $1(3.3)$ \\
\hline
\end{tabular}

patients during the acute phase of SARS-CoV-2 infection, fever was the most commonly reported symptom in 14 $(46.6 \%)$ patients, rhinorrhoea in $8(26.7 \%)$ and cough was present in $7(23.3 \%)$, with remaining symptoms presented in table 1. Patients were assessed a mean of 101 (SD, 17) days after onset of the first SARS-CoV-2 infection symptom. None of the patients had any symptoms of acute illness. At the time of the follow-up visit, 21 (70\%) were completely free of any COVID-19-related symptoms, while $9(30 \%)$ had at least one symptom. Table 2 shows that patients at the time of the follow-up visit reported prolonged low-grade fever, swollen lymph glands, joint pain, headache, anosmia, ageusia and microhaematuria.

\section{DISCUSSION}

The COVID-19 postacute outpatient service is currently active and we plan to actively assess children after acute COVID-19 phase in follow-up visits. This study identified that in patients who had recovery from SARS-CoV-2 infection, 30\% reported for a prolonged time at least one symptom, even though children are more likely to have a mild infection. The limitations of this study include a small sample size of patients and the absence of a control group making comparison impossible.

Correction notice This article has been corrected since it was first published. Provenance and peer review statement has been added.

Contributors LS collected and analysed the data and wrote the first draft of the manuscript. All authors collected the data, contributed to the study design, revised the manuscript and approved the final version.

Funding This study was supported by the National Research Program to Mitigate Consequences of COVID-19 (VPP-COVID-2020/1-0011).

Competing interests None declared.

Patient and public involvement Patients and/or the public were not involved in the design, or conduct, or reporting, or dissemination plans of this research.

Patient consent for publication Not required.

Ethics approval The study protocol questionnaire and informed consent forms were reviewed and approved by the ethics committee of Riga Stradins University and by the Institutional Review Board of Children's Clinical University Hospital (No. $6-1 / 07 / 35)$.

Provenance and peer review Not commissioned; externally peer-reviewed.

Open access This is an open access article distributed in accordance with the Creative Commons Attribution Non Commercial (CC BY-NC 4.0) license, which permits others to distribute, remix, adapt, build upon this work non-commercially, and license their derivative works on different terms, provided the original work is properly cited, appropriate credit is given, any changes made indicated, and the use is non-commercial. See: http://creativecommons.org/licenses/by-nc/4.0/. 
ORCID iD

Liene Smane http://orcid.org/0000-0002-1579-3715

\section{REFERENCES}

1 Lu X, Zhang L, Du H, et al. SARS-CoV-2 infection in children. $N$ Engl J Med 2020;382:1663-5.

2 Mannheim J, Gretsch S, Layden JE, et al. Characteristics of hospitalized pediatric coronavirus disease 2019 cases in Chicago, Illinois, March-April 2020. J Pediatric Infect Dis Soc 2020;9:519-22.
3 CDC COVID-19 Response Team. Coronavirus Disease 2019 in Children - United States, February 12-April 2, 2020. MMWR Morb Mortal Wkly Rep 2020;69:422-6.

4 Carfi A, Bernabei R, Landi F, et al. Persistent symptoms in patients after acute COVID-19. JAMA 2020;324:603-5.

5 Tenforde MW, Kim SS, Lindsell CJ, et al. Symptom Duration and Risk Factors for Delayed Return to Usual Health Among Outpatients with COVID-19 in a Multistate Health Care Systems Network United States, March-June 2020. MMWR Morb Mortal Wkly Rep 2020;69:993-8.

6 Hoang A, Chorath K, Moreira A, et al. COVID-19 in 7780 pediatric patients: a systematic review. EClinicalMedicine 2020;24:100433. 